\title{
The Transformation of Special Provincial Administration System in Turkey
}

\author{
Assistant Proffessor Dr. Zuhal Önez Çetin \\ Uşak University, Public Administration Department, Head of the Local Government Studies \\ zuhal.cetin@usak.edu.tr, zuhalonez@gmail.com
}

\author{
Doi:10.5901/mjss.2015.v6n3p138
}

\begin{abstract}
The Law No. 6360 on 'The Establishment of Fourteen Metropolitan Municipalities and Twenty-seven Districts and Amendments at Certain Law and Decree Laws' brings significant changes in Turkey's local government system. In this framework, the first objective of the article is examining the change and transformation of the Special Provincial Administrations (SPAs) at the historical perspective until the Law No. 6360 in Turkey. The second objective of the article is examining the new arrangements of Law No. 6360 in detail that entered into force in 2012 within the context of SPA. In that context, one of the new arrangements of that reference Law is the establishment of Investment, Monitoring and Coordination Directorates' (IMCDs) instead of the abolished SPAs at the provinces having metropolitan municipalities. At that scope, the IMCDs emergence, duties, powers and responsibilities are searched in detail in comparison with the SPAs in Turkey. Finally, it is seen that IMCDs and SPAs have lots of differences in terms of supervision authority, duties and responsibilities, financial, personnel and organizational structure.
\end{abstract}

Keywords: Special Provincial Administration, Law No. 6360, Investment, Monitoring and Coordination Directorate

\section{Introduction}

By the Law No. 6360 on 'The Establishment of Fourteen Metropolitan Municipalities and Twenty-seven Districts and Amendments At Certain Law and Decree Laws', the local government system ${ }^{1}$ has undergone radical changes in Turkey in terms of administrative structure, distribution of the financial resources, at the provision of the local services and lastly, in the fields of development and planning schemes. In that context, the number of the metropolitan municipalities upgraded to 30, and SPAs were abrogated at those provinces having metropolitan municipalities and the villages turned to the neighborhoods and 27 new districts were established within the borders of the metropolitan municipalities by the Law No. 6360. One of the key features of that relevant Law was the abolition \%36 of the SPAs, $\% 53$ of the municipalities and \%47 of the villages in Turkey (Güler, 2012a:1). By the new Law, critical amendments were made at administrative structure (the removal of legal entities, the establishment of new corporate entities, the amendment at administrative commitment, the changes at borders and division of powers), financial system (redetermination of the shares of local governments and new distributional relations), political geography (the change at the dimension of representation and participation with the change at election zones), personnel structure, the provision of services/ service delivery ( the expansion of the service area with the expansion of the municipal borders to provincial borders) and development and planning order (İzci and Turan, 2013: 119). As it is seen from the clarifications, it is clear that the Law No. 6360 will lead to significant changes at the local government system in Turkey with its new arrangements. Within the framework of the article, that reference Law has been searched in detail in terms of its effect on SPAs administrative system in Turkey. In this study, the SPAs, one of the oldest local government unit of Turkish local administrative system, and Investment, Monitoring and Coordination Directorates (IMCDS) that are established instead of the SPAs at the provinces having metropolitan municipalities that are depended to the Governorate are selected for detailed examination. Furthermore, at

\footnotetext{
1 There are four types of local government, including metropolitan municipal administrations in Turkey. Special provincial administration means a public entity having administrative and financial autonomy which is established to meet the common local needs of the people in the province and whose decision-making body is elected by voters; Municipality means a corporation established in the statute of public legal entity having powers of self-government (autonomous) both administratively and financially, to meet the local and common requirements of the county inhabitants and the decision maker of which is elected by the electors. Metropolitan municipalities means administratively and financially autonomous public legal entity of which decision making organs are elected by the voters and which comprises at least three district or first degree municipality; establishes coordination between the municipalities: undertakes the duties and responsibilities conferred upon by the laws: and uses its powers whenever deemed necessary, and the headman (mukhtar) and elected elders' council are governed the villages (Kapucu \& Palabıyık, 2008: 137).
} 
the study, a historical research design is used with starting from 'Regulation of Provinces' which was enacted in 1864 to the Law No. 6360 that was put into force in 2012, for examining the previous and current legal and administrative grounds of SPAs. Besides, by the historical research method, the reform efforts at the local government system in related with SPAs, the proposed solutions towards the problems of SPAs at the government reports and SPA Laws have been examined in detail up to the abrogation of public legal entities of SPAs at the provinces having metropolitan municipalities with the Law No. 6360 at Turkish administrative system.

Within the context of the article, the first objective is to put forth historical background to demonstrate the transition of SPAs' at Turkish administrative system. The examination of the historical perspective is significant for the study at indicating the previous and current problems of SPAs such as the insufficiency of organizational formation, service capacity, equipment and facilities, financial revenue, and human resource. The presence of SPAs and their necessity at the Turkish local government system started to be discussed since the 1960s, and those mentioned problems caused the discussion of the abrogation of SPAs at the local government system. Besides, the second objective of the study is related to the examination of the Law No. 6360 enacted in 2012 with its key provisions and aspects in relevant with the SPAs. That recent Law is noticeable for Turkey's local government system because it leads to the abolition of the SPAs in Turkey at the provinces having metropolitan municipalities. In that context, IMCDs' are established by the Law No. 6360 instead of SPAs that their public legal entities removed in the provinces where metropolitan municipalities' established; however, there are significant differences between IMCD and SPA. Lastly, a comparison is tried to be made between the SPAs and the newly established IMCDs in Turkey with putting forth the main differences in terms of supervision authority, administrative tutelage, duties and responsibilities, finance, personnel structure and organizational formation.

\section{Historical Background of Special Provincial Administrations in Turkey}

SPAs are the local government units inherited from the Ottoman Empire. SPAs were established with the 'Regulation of Provinces' (Vilayet Nizamnamesi) in 1864 and those local government units had a local administrative formation inspired by the French administrative system during the Ottoman Empire period (Parlak \&Sobacı, 2005: 79, Tortop et al., 2014: 165). One of the most striking aspects of 'Regulation of Provinces' was the provincial organization of the Ottoman Empire which was revised by that regulation and the provincial administrative system was set up to replace the existing stateseyalet- with new provincial-vilayet- system (Kapucu \&Palabıyık, 2008: 138). By the 'Regulation of Provinces', a Provincial General Council (Vilayet Umum Meclisi) was established that composing from the councilors elected among local citizens under the leadership of the Governor. The duties and powers of Provincial General Council have been increased by the 'General Administration of Provinces Law' dated 1870 (Idare-i Umumiye-i Vilayet Nizamnamesi) (Ortayll, 1974: 79).

However, provinces peculiarity of being an autonomous decentralized administrative formation was firstly decided at the Constitution of 1876 (Kapucu \&Palabıyık, 2008: 138). At the $11^{\text {th }}$ section of the Kanun-u Esasi that consisting of 12 parts; the principles and procedures of provinces were arranged between the items of 108-112. In that scope, deconcentration (Tevsii mezuniyet) and segregation of duties (Tefriki vezaif/ yetki genişliği/ görevler ayrılığı) principles had been adopted at the provincial administration by the $108^{\text {th }}$ item (Reyhan, 1982). Those principles which have been adopted in theoretical terms by the 'General Administration of Provinces Temporary Law' (Idare-i Umumiyye-i Vilayat Kanun-u Muvakkat) in 26 March 1913 take the possibility to adjust at the application process (Kartal, 2010: 62). According to the General Administration of Provinces Temporary Law', the provinces are regulated not only as an extension of the central government but also as a local government unit having a public legal entity. As similar to the $108^{\text {th }}$ item of the 1876 Law of Kanun-u Esasi; it was determined that the provinces have been established as to the principles of deconcentration and segregation of duties (Kartal, 2010: 62).

By the 1921 Constitution (Teşkilat-ı Esasiye Kanunu), it was intended to give a new formation to the local administrative structure of SPAs. In this sense, the 1921 Constitution recognized autonomy to the local governments. That related Constitution had given special attention to the administration of the provinces and dedicated a special part towards the provinces (Nalbant, 1997: 167). According to that Constitution, provincial general council was called as 'Provincial Council' (Vilayet Şurası) and councilors had been elected for two years by the citizens of the province and the councils meetings were convened twice a year. That related Constitution did not determine Governor as the head of the Provincial Council (Vilayet Şurası); whereas Governor had only the authority to intervene a dispute that may arise between the state's general affairs and local affairs. Within the framework of that Constitution, it is stipulated that Provincial Councils shall elect the chairman among the representatives of the provincial council, and this chairman will be the chief executive (Alpay, 1965: 27). On the contrary, by the 1924 Constitution, Turkish local government system again returned to the basis of deconcentration and segregation of powers (Ülkmen, 1960: 120-121). Furthermore, 1924 Turkish 
Constitution had a different context from the 1921 Constitution concerning the local governments, and that related Constitution revealed the basic principles that were founded by the 1876 Constitution. It is worth pointing out that 1921 Constitution adopted the separation of state's general affairs and province local affairs; however, the term of province local affairs was not used in the 1924 Constitution and only the term of province affairs was expressed within the context of that Constitution. That related amendment is the indication of the adoption of a centralist tendency at the administration system (Nalbant, 1997: 171). Likewise, there was no provision in relevant with the provincial administration and local governments at the 1924 Constitution but there were expressions concerning SPAs and municipalities at the $85^{\text {th }}$ Article of the Constitution (Güneş, 2013: 61). In that regard, within the years of 1920s and 1930s, many tasks of the SPAs were transferred to different administrative units (ministries and municipalities) at various laws enacted at that related period (Ateş \&Es, 2008: 205-210). In that context, Kapucu and Palabıyık (2008: 138) clarified those words in relevant with that related period;

SPAs carried out important duties in the first years of Republic. However, many tasks belonging to these units were later undertaken by various ministries and central administrative organizations as the relevant organizational laws appeared on the statue books.

By the 'Provincial Administration Law' No. 1426 that was put into force in 1929, the first part of 1913 dated Law was abrogated in relevant with the provincial administration. By that reference Law, two administrative units at the provincial level-Governorate and SPA- separated at the legal dimension. By the 'Law on Provincial Administration' No. 5442 that was put into force in 1949, the Law No. 1426 was subject to revision in terms of Turkish language 2 . In that context, Güler (2006: 219) puts forwards the view on the historical perspective in relevant with the provincial special administrations as follows;

SPAs have a more important place than the municipalities at the local government system in the period of 19301945. However, at the period of 1946-1960, the significant tasks of the SPAs were transferred to the central government. Therefore, the municipalities came to the front side instead of the SPAs.

Following that period, by the enactment of the 1961 Constitution; the local governments are formulated in the Article of the $116^{\text {th }}$ as follows:

Local administrative bodies are public corporate entities created to meet the common local needs of the citizens of provinces, municipal districts, villages, whose policy-making organs are elected by the people. The elections of the local administrative bodies shall be held at such times as prescribed by law and subject to the provisions of Article 55 of this Constitution ${ }^{3}$.

In this regard, some of the tasks of the SPAs in time transferred to the regional directorate that incorporating more than one province. Thus, the SPAs turned to the local government units that cannot fulfill their responsibilities and launched to encounter with the problems of the insufficiency of organizational formation, service capacity, financial and human resource (Kaya, 2011: 30 ).

It is also noticeable that the presence of SPAs and their necessity within the Turkish administrative system have been started to be discussed since the 1960s. At that point, there was an ample support for the claim that SPAs lost its efficiency in the local government system and it should be abrogated at the local government system in Turkey (Keleş \&Yavuz: 78; Güran, 1986: 74). The people who have the opinion of the abrogation of the SPAs have those justifications concerning the problems of SPAs which can be listed as follows (Keleş, 2006: 80; DPT, 1991: 125-126; Keleş \&Yavuz, 1983: 78-80):

- Many of the duties of SPAs that are not explicit, in time are undertaken by the central government organizations; however those related tasks are not removed from the responsibility area of the SPA. Therefore, SPAs have almost any responsibility and authorized service fields at the provision of the local services.

- The financial revenue, staff, equipment and facilities' of the SPAs are inadequate to fulfill their local tasks.

- The principles of democratization, autonomy, subsidiarity, and public participation are not settled at the local administrative system of SPAs that are required for being a local government unit.

- SPAs could not be an original local government unit; that local government unit is transformed into a structure that carrying the features of central government. SPAs are mostly remained under the influence of the central government. Therefore, a large proportion of the people in Turkey do not know that related local government

\footnotetext{
${ }^{2}$ By the Law No. 3360 that was put into force on 16 May 1987, which was issued with 19471 numbered Official Gazette, 1913 dated Law's name changed as 'SPA Law'.

${ }_{3}^{3}$ For details, see, http://www.anayasa.gen.tr/1961constitution-text.pdf, 'Constitution of Turkish Republic'. 
or see it as a central government unit. Hence, the local services that are undertaken by the SPAs, perceived as central government oriented services (Kartal, 2010: 113).

In addition to that, there have been also dissenters to the abrogation of SPAs (Başsoy, 1976: 70-71, Güler, 1995: 11, Gözübüyük, 1967: 100). The opponents' demonstrate the most important reason for not abrogating the SPAs in Turkey at their being of constitutional institutions. Besides, another justification at that point is pertinent with financial resource and technical possibilities; that justification rests on the assumption that if the adequate financial resource and other possibilities have been given to the SPAs, those local governments can fulfill their assigned services; they also proved that related case in the past. In particular, another relevant aspect at that point is pertinent with the entailment of a more functional and strong SPAs at the rural field in the lacking of a management gap. In this scope, when SPAs are abrogated, there would be no administrative unit to provide services to the rural field and at that related field administrative and service unit weakness shall be occurred (Kartal, 2010: 114).

One of the other prominent features of the 1960s was relevant to the reform process, as well as the public administration, reform efforts at local governments started to be accelerated at the planned period in Turkey. The first and the most comprehensive restructuring study of the planned period was the MEHTAP (Merkezi Idare Teşkilatı Araştırma Projesil Central Government Organization Research Project) that was prepared by TODAIE ${ }^{4}$. In this research, central government and central government organization's provincial units, the distribution of responsibilities between local governments, powers of local governments, resources and organization issues represented an important area of investigation. At the result of this research, it was determined that those issues listed above should be examined and discussed one by one. Besides, it was also emphasized that the structural problems of the local governments and their relation with central government should be examined separately (Urhan, 2008: 70). Moreover, by the target of restructuring and developing local governments, "Ministry of Interior Restructuring of Service and Organization Project which was also called as 'Internal Regulation Project', in the years 1967-1971, was formed by the Ministry of Interior. In this scope, 'Internal Regulation Project' was the first research on Turkish Public Administration by a Ministry. At this Report, SPAs tasks evaluated one by one and later, it was expressed that many of those tasks have been fulfilled by central government (Şeyran, 1996: 52). By the 1971 onwards, the restructuring of administration issue came up again to the political agenda and a committee with the name of 'Administrative Reform Advisory Committee' established by the government for the determination of precautions on administrative system. That related Committee's works were presented to the public with the report titled 'Administrative Reform Advisory Committee Report: Restructuring of Administration Principles and Recommendations' in $1972^{5}$. At that report those following proposals have been expressed such as; to strengthen the local autonomy of local governments, to reduce the authorities of the public administrations that use the administrative tutelage and to make cooperation between them, to pay attention in gathering the authority at the sub-governor in the district level (Ökmen, 2003: 124). In accordance with the prepared Report, a determination was made concerning the SPAs as follows: the existing structure is away from the good-functioning of a healthy service provision and this case led to the disruption at the performing of education, health, and agriculture services especially in rural fields (Kaya, 2011: 30).

Furthermore, at the last period of the 1970s, the Ministry of Local Government was established in 1978 to resolve the administrative and financial bottlenecks of local governments and to make the arrangements for the effectiveness of the local governments in Turkey. At that point, it is noticeable that while that Ministry's name is called as the Ministry of Local Government, that related Ministry served as a Ministry of Municipalities and it did not contribute to the SPAs local administrative system. At last, that related Ministry was abrogated in November 1979 (Keleş, 2000: 369).

Besides, in Turkey, by the 1980s onwards, the existence of SPAs has been adopted by also the Constitution and that local government unit was determined as a public institution having public legal entity. At the 1982 Constitution at the Article $127^{\text {th }}$, it was determined that:

Local administrations are public corporate bodies established to meet the common local needs of the inhabitants of provinces, municipal districts and villages, whose principles of constitution and decision-making organs elected by the electorate are determined by law. The formation, duties and powers of the local administrations shall be regulated by law in accordance with the principle of local administration.

In addition to that, by the 3360 Numbered Law, dated 26 May 1987, 'Provincial Administration Law' No. 1426 dated 1929 name has been changed to 'SPA Law'. In this context, while the Law No. 3360 brought new provisions to the SPAs

${ }^{4}$ For Details, see, MEHTAP Projesi, www.todaie.gov.tr (10.11.2014).

${ }^{5}$ For Details,see, Talat Bayraktar, "Türkiye'de Idareyi Geliştirme Çalışmalarının Tarihsel Gelişimi", http://www.igb.gov.tr/Forms/p GecmisDonemCalismalari.aspx (10.01.2015).

${ }^{6}$ For details, see, http://global.tbmm.gov.tr/docs/constitution_en.pdf, 'Constitution of the Republic of Turkey'. 
and made some amendments in some articles, it did not touch on most of the provisions of 'Provincial Administration Law' No. 1426 (Keleş, 1994: 113). By the Law No. 3360, significant responsibilities have been given to the SPAs such as education, health, agriculture, and animal husbandry. On the contrary, those listed services have been undertaken by the central government that it led to authority conflict between central and local governments, and those local government units turned to dysfunctional and ineffective institutions (Ulusoy \&Akdemir, 2008: 159; TOBB, 1996: 114). Furthermore, SPAs also faced with the problem of the staff in terms of its decreasing number and quality owing to the fact that the negligence of the central government (Tortop, 2006: 130).

On the other hand, by the 1990s onwards, a new approach that perceived a new distribution of power between the local and central government was observed in the prepared draft laws, development plans, and at KAYA (Public Administration Research Project) Report. However, the local government reform planning to be made within the framework of that new responsibility and power distribution would result in the restructuring of social relation and this kind of manner entails not only a strong common will and but also an effective and decisive political will that this new understanding could not find the possibility of realization (Güler, 2001: 7).

In addition to that, Turkey was introduced with 'Public Administration Basic Draft Law', and Turkey quickly and deeply felt the results of that draft Law that composed of 73 items by the 2000s onwards (Güler, 2005: 161). In this scope, $58^{\text {th }}$ Government perceived a new responsibility and authority distribution between central and local governments with that related Law draft. In that context, most of the duties and responsibilities that have been carried out by the central government are declared to be transferred to the SPAs as a necessity (Coşkun \&Uzun, 2005: 157). In this regard, 'Basic Law of Public Administration' that has been presented to the Grand National Assembly on 15 July 2004 was enacted by the Law No. 5227 on 'Basic Principles of Public Administration and Its Restructuring'. In that context, the Law No. 5227 dated 3 August 2004 was returned by the $10^{\text {th }}$ President of Ahmet Necdet Sezer with finding most of the items of the Law unconstitutional and it was returned to the Grand National Assembly for reconsideration and it could not find the possibility of legalization (Kaya, 2011: 31). In that scope, while the Law text was not adopted that formed the legal framework of the reform of public administration, the Law of Public Finance Management, Metropolitan Municipality Law and Special Provincial Law that complement the reform process entered into force by one by in Turkey (Kapucu \&Palabıyık, 2008: 195).

In that context, the process of restructuring of public administration that was launched in 2003 in Turkey resulted in the SPA Law within the framework of searching solutions to the problems of SPAs (Parlak \&Ökmen, 2008: 135). Afterward, the reform expectations and suggestions have continued to increase in the local government field. Until the SPA Law No. 5302, many draft laws and drafts have been prepared by the governments coming to the power, but those reform-making efforts could not find the chance of realization (Kartal, 2010: 89). Finally, the SPA Law No. 5302 discussed at the Grand National Assembly on 22 February 2005 and entered into force with the published Official Gazette dated 4 March 2005 (Tortop et al., 2014: 165-166). Within the framework of the article, the most significant issue concerning SPAs is its abrogation of the public legal entity at the provinces having metropolitan municipality by the Law No. 6360 that was enacted in 2012. Within the scope of the Law No 6360, 'Investment, Monitoring and Coordination Directorates' have been established instead of the SPAs in the provinces having metropolitan municipality.

\section{The Law No. 6360 on 'The Establishment of Fourteen Metropolitan Municipalities and Twenty-Seven Districts and Amendments at Certain Law and Decree Laws'}

The Municipal Law No. 6360 on 'The Establishment of Fourteen Metropolitan Municipalities and Twenty-seven Districts and Amendments at Certain Law and Decree Laws' entered into force with the published Official Gazette dated 06.12.2012 and numbered 28489. By that Law, the metropolitan municipality numbers upgraded from 16 to 30 , and all metropolitan municipality borders were expanded to the provincial borders up to the end of the mentioned year (Zengin, 2013: 543).

In this regard, the new metropolitan system leads to structural changes in terms of administrative, financial, zoning, and planning order. By the new Law, critical amendments were made at administrative structure (the removal of public legal personalities, the establishment of new public legal personalities, the amendment at administrative commitment, the changes at borders and division of powers), financial system (redetermination of the shares of local governments and new distributional relations), political geography (the change in the dimension of representation and participation with the change at election zones), personnel structure, the provision of services/ service delivery (the expansion of the service area with the expansion of the municipal borders to provincial borders) and development and planning order (İzci \&Turan, 2013: 119).

The Law No. 6360 that came into force after 30 March 2014 General Elections for Local Governments put forth 
those following issues listed below;

- SPAs' were removed from the cities where metropolitan municipalities were established and IMCDs were established instead of the closed SPAs at 30 provinces.

- Metropolitan municipality borders were expanded to provincial borders.

- 14 new metropolitan municipality were established.

- $\quad$ The villages turned to neighborhood at the cities where metropolitan municipalities were established, and 500 population criterion was introduced at the establishment of neighborhood within the borders of municipalities?.

- 25 new districts established within the borders of the metropolitan municipalities.

- Local government unions were abolished in the cities where metropolitan municipalities were established.

- The shares transferred to the municipalities from the general budget tax revenue were rearranged (Genç, 2014: 4-5).

As it is seen from the above clarifications, the SPAs were abrogated at thirty provinces having metropolitan municipalities by the Law No. 6360 in Turkey. At that reference Law, it was expressed that all types of movable and immovable property, rights, receivable, and debts of SPAs by a commission to be formed shall be shared among the public institutions (Temporary Item 1/5). Additionally, the provisions concerning IMCD are stipulated in the Article $34^{\text {th }}$ of Law No. 6360 to fulfill the administrative gap that is stemmed from the abrogation of the SPAs. In that scope, by the Law No. 6447 dated 14.03.2013, SPAs were abrogated at 14 provinces that were turned into metropolitan municipality status and other 16 provinces having metropolitan municipality status, and IMCDs set up that are tied to Governorates at those related provinces. The target of the IMCD is determined at the Article $34^{\text {th }}$ of the Law No. 6360 as follows;

To increase the effectiveness and efficiency of the services concerning the central government affairs carrying at the local level, to ensure the financial resources in an efficient way, to carry out disaster and emergency services, to prevent the disruption of services, to fill the gap in relevant with supervision and guide to it?.

It is possible to clarify that IMCDs take over the duties of SPAs aside from the sending of the report to the Prime Minister and the affiliated or related Ministry of those institutions (Zengin, 2014: 102-103). Likewise, Güler (2012b: 104) also clarified that when the listed tasks, powers, and responsibilities have been examined at the Law No. 6360, it can be stated that the newly established administrative unit is the 'alternative province general administration' enabling the provincial general administration. Additionally, at the Ministry of Interior Directive, at the Article $7^{\text {th }} / 1-a$, it is expressed that the Ministries and other central government agencies with the provision of the transferring resources can make any investment, construction, and maintenance, and repair affairs through this Directorate (Güngör, 2012: 28). As it is seen from those clarifications, as contrary to the decentralization approach, SPAs were closed at 30 metropolitan municipality and Investment, Monitoring, and Coordination Directorates tied to the Governorships.

\section{The Main Differences between SPAs and IMCDs}

\subsection{Within the Scope of Supervision Authority and Administrative Tutelage:}

In Turkey, local governments have public legal entity and they are established to meet the common local needs of the inhabitants of provinces, municipal districts and villages, whose principles of constitution and decision-making organs elected by the electorate are determined by law. The principle of decentralization applies to them, and they are autonomous from the central government in terms financial and administrative autonomy that does not involve an unlimited freedom ${ }^{9}$. In that framework, at the Turkish Constitution dated 1982, at the Article $127^{\text {th }}$, local administrations have been stipulated with those expressions as follows:

Local administrations are public corporate bodies established to meet the common local needs of the inhabitants of provinces, municipal districts and villages, whose principles of constitution and decision-making organs elected by the electorate are determined by law. The formation, duties and powers of the local administrations shall be regulated by law in accordance with the principle of local administration. The central administration has the power of administrative tutelage over the local administrations in the framework of principles and procedures set forth by law with the objective of ensuring the functioning of local services in conformity with the principle of the integrity of the administration, securing

\footnotetext{
7 For detail, see, Article 15 of Law No. 6360.

${ }^{8}$ For details, see, http://www.tbmm.gov.tr/kanunlar/k6360.html, 'On Ü̧̧ Illde Büyükş̧ehir Belediyesi ve Yirmi altı Ilı̧e Kurulması ile Bazı Kanun ve Kanun Hükmünde Kararnamelerde Değişiklik Yapılmasına Dair Kanun'.

${ }_{9}^{9}$ For Details, see, http://www.migm.gov.tr/en/PDF/Generallnformation.pdf, 'Local Governments in Turkey',pp.10-19.p.15. 
uniform public service, safeguarding the public interest and meeting local needs properly ${ }^{10}$.

As it was seen from the Article, the central government has the power of administrative tutelage over the local governments in the framework of principles and procedures set forth by law. In that regard, the new local government laws that are regulating the central and local government relations have the objective to constraint the central government's administrative tutelage over local governments ${ }^{11}$. In Turkey, administrative and financial decentralization supported with the major Laws such as Public Financial Management and Control Law No. 5018, Metropolitan Municipality Law No. 5216, SPA Law No. 5302, Law of Unions of Local Governments. In this sense, the general objective of those Laws focused on reducing the administrative tutelage on local governments, and expanding the local autonomy of local governments. At that point, it is noticeable that local autonomy is a tool at the realization of effectiveness and efficiency at the local services that the whole reforms and local regulations intended to provide the effectiveness and efficiency are consistent with autonomy (Pirler et al., 1995: 32). The autonomy in terms of local government means the provision of the significant proportion of public services that are determined by the Constitution and the Laws under the responsibility of the local governments for the benefit of the local citizens ${ }^{12}$. In that context, the most important issue concerning the autonomy of the local administrations is pertinent with the using of right of management by the decisionmaking organs composed of elected representatives (Arıkboğa, 2007: 56). According to Bilgiç (2007: 12), the administrative tutelage at the SPAs was eased by the SPA Law No. 5302. Besides, the budget of the SPAs has been approved with the opinion of Provincial Executive Committee, and the procedure of the approval of the budget of the SPAs to the Ministry of Interior application was removed with that related Law. This case is a striking development in terms of the autonomy of the SPAs and the alleviation of the administrative tutelage on those local government units (Sobacı, 2005: 48). In the light of those clarifications, by that reference Law, at the finalization of the Council resolutions and their application process, the governor and the central government will are not the only determiner; the examination to be conducted on council decisions degraded to only the legal audit (Günday, 2005: 166). Moreover, the provincial general council launched to be convened at each month instead of twice a year that this procedure is a positive development in terms of accountability and transparency of the local administration (Kızılboğa \&Özaslan, 2013: 13). That related provision can be seen at the Article $12^{\text {th }}$ of the SPA Law No 5302; the general provincial council meetings have been determined in detail;

The general provincial council shall meet in its usual venue in the first week of every month, excluding the onemonth vacation to be determined by the general provincial council, on the date determined in advance by the general provincial council ${ }^{13}$.

However, while on the one hand positive steps have been taken in the development of the local autonomy, on the other side the local government's relation with the local community have been negatively affected by the abolition of the decision-making organ of the general provincial councils of SPAs with the Law No. 6360 (Arıkboğa, 2007: 45). By the abolition of the legal entities of SPAs, first-tier municipalities and villages; provincial general directorates, municipal councils, and village elderly councils' decision-making organs are also closed. Thus, the citizens' participation in the decision-making mechanisms would be decreased to a certain extent (Adıgüzel, 2012: 172).

In that context, IMCDs' are established by the Law No. 6360 instead of SPAs that their public legal entities removed in the provinces where metropolitan municipalities established; however, there are significant differences between IMCD and SPA. First of all, one of the most prominent differences is focused on their administrative formations; SPAs are local government institutions, whereas IMCDs' have been stipulated as a local unit of the central government at the Metropolitan Municipality Law No. 6360. Furthermore, the internal and external supervision has been perceived for SPAs with the Law No. 5018, however, internal supervision has not been foreseen for IMCD (Karaaslan et al., 2012: 126). At the Law No. 5302 of SPA under the title of scope and types of supervision at the Article 38; it was determined that;

Special provincial administrations shall be subject to internal and external supervision. Supervision shall cover the legal compliance of acts, and financial and performance auditing. Internal and external supervision shall be conducted in accordance with the provisions of the Law No. 5018 on Public Fiscal Administration and Control. Furthermore, the administrative acts of the SPA other than the financial transactions shall also be audited by the Ministry of Interior, by the governor or by the staff members to be assigned duty by the governor, in terms of compliance with the integrity of

${ }^{10}$ For details, see, http://global.tbmm.gov.tr/docs/constitution_en.pdf, 'Constitution of the Republic of Turkey'.

${ }^{11 F}$ For Details, see, http://www.migm.gov.tr/en/PDF/Generallnformation.pdf, 'Local Governments in Turkey',pp.10-19.p.15.

${ }^{12}$ For Details, see, http://www.anayasa.gov.tr/eskisite/KARARLAR/IPTALITIRAZ/K1988/K1988-23.htm.

${ }^{13}$ For Details, see, http://www.migm.gov.tr/en/Laws/Law5302_SpecialProvincialAdmin_2010-12-31_EN_rev01.pdf 'Law on Special Provincial Administration'. 
administration as well as with the development plan and strategies. Affiliated entities and enterprises of the special provincial administrations shall be audited in accordance with the principles mentioned above. The outcome of audits shall be made public, and communicated to the general provincial council14.

At the Law No. 6360, there are no provisions concerning the supervision of IMCD. Moreover, General Provincial Council of SPA has the authority to supervise the SPA that can be seen on the Article $17^{\text {th }}$ of the Law No 5302. At the Article 17; it was determined that;

The general provincial council shall, at each January meeting, form by balloting an audit commission of three to five persons from among its own members to audit the revenues and expenditures and related accounting records and transactions of the SPA for the previous year. The commission shall be formed according to the ratio of the number of members of each political party group and the number of independent members in the general provincial council to the total number of members of the councill15.

In that scope, at the Law No. 5302, under the title of Council's means to obtain information and exercise supervision, the activities of the SPAs can be monitored by the local representatives that were expressed in the Article 18, as follows;

The general provincial council shall exercise its powers to obtain information and supervise through questions, general debates and its assessment of the activity report. In the March meeting, the governor shall present the activity report of the previous year to the council. If a majority of three-quarters of the full membership of the council considers that the explanations given in the activity report are unsatisfactory, the resolution on the report's being unsatisfactory and the record of the debates shall be communicated to the Ministry of Interior for action ${ }^{16}$.

In this regard, IMCD is a part of the central government that IMCD is not subject to supervision by a local council. Besides, SPAs have no authority in the supervision of the other public institutions and organizations. However, IMCD has the supervision power in the public institutions and organizations in the province via the Report which will be prepared by IMCD concerning the effectiveness and efficiency of the services and activities and the institutions compliance with the strategic plan and performance program of the all units at the local level excluding the judicial and military organization of central government (Karaaslan et al., 2012: 125). In that framework, while at one side decentralization has been advocated by the local laws to improve the local autonomy fields of the local governments, from the other side with the establishment of the IMCDs with the Law No. 6360, the using of the administrative tutelage by the governor has been facilitated on local government units in Turkey.

\subsection{Within the Scope of Duties and Responsibilities:}

At the Law No. 5302 of SPA in the Article $3^{\text {th }}$ that was put into force on 22 February 2005; SPA is determined with those clarifications;

Special provincial administration means a public entity having administrative and financial autonomy which is established to meet the common local needs of the people in the province and whose decision-making body is elected by voters ${ }^{17}$.

It is apparent from the above determination that SPAs are the local government units established to carry out local services at their respective provinces beyond the boundaries of the municipal administration. In this sense, according to SPA Law No. 5302, Article 4, it is illuminated that "SPA shall be established by the law concerning the establishment of a province and its legal personality shall cease to exist when the province is abolished" ${ }^{18}$. Furthermore, the duties and responsibilities of the SPAs have been stipulated in the Law No. 5302 of SPA in the Article $6^{\text {th }}$ as follows; Provided that such services be of local and common nature, the SPA shall be mandated and authorized to provide:

a) Services that are related to youth and sports, health, agriculture, industry and trade; except for those metropolitan municipalities whose boundaries are the boundaries of the province, provincial environmental

14 For Details, see, http://www.migm.gov.tr/en/Laws/Law5302_SpecialProvincialAdmin_2010-12-31_EN_rev01.pdf 'Law on Special Provincial Administration'.

${ }^{15}$ For Details, see, http://www.migm.gov.tr/en/Laws/Law5302_SpecialProvincialAdmin_2010-12-31_EN_rev01.pdf 'Law on Special Provincial Administration'.

16 For Details, see, http://www.migm.gov.tr/en/Laws/Law5302_SpecialProvincialAdmin_2010-12-31_EN_rev01.pdf 'Law on Special Provincial Administration'.

17 For Details, see, http://www.migm.gov.tr/en/Laws/Law5302_SpecialProvincialAdmin_2010-12-31_EN_rev01.pdf LLaw on Special Provincial Administration'.

${ }_{18}$ For Details, see, http://www.migm.gov.tr/en/Laws/Law5302_SpecialProvincialAdmin_2010-12-31_EN_rev01.pdf 'Law on Special Provincial Administration'. 
plan, public works and settlement, conservation of soil, prevention of erosion, culture, arts, tourism, social services and aids, provision of micro credits to the poor, day care centres and orphanages; provision of land lots to primary and secondary education institutions, construction, maintenance, and repair work of the buildings, as well as services to respond to other needs within the boundaries of the province;

b) Services that are related to land development planning and control, road, water, sewer, solid waste, environment, emergency aid and rescue; supporting the forest villages, forestation, establishment of parks and gardens outside the municipal boundaries. (Supplementary paragraph: 3/7/2005-5393/85 Art.; Amended second paragraph: 24/7/2008-5793/42 Art.) Ministries and other central government agencies may realize the investments relating to such services as construction, maintenance and repair works, state and provincial roads, potable water, irrigation water, sewer, power transmission lines, health, education, culture, tourism, environment, land development planning and control, public works, settlement, youth and sports, and other investments within the purview of ministries and other central government agencies by transferring the appropriations in their budgets earmarked for such services to the special provincial administrations ${ }^{19}$.

Furthermore, at the Law No. 6360 at the item 28/ A; the responsibilities and duties of IMCD at the provinces having metropolitan municipalities have been expressed as follows;

- Making the investment and the services of the public institutions in an effective way, its monitoring and coordination,

- Coordinating and functioning of emergency call, disaster, and emergency assistance services,

- The publicity of the city,

- Coordinating and making the investments of the central government in the locality when necessary,

- Performing the representation, ceremony; rewarding and protocol services,

- Providing the guidance to public authorities and institutions in the city and realizing their audit,

- Guiding the public institutions and organizations at the city and realizing their audit20.

In the light of those clarifications, it is apparent that one of the most prominent differences between SPAs and IMCDs sourced from their duties and powers that are expressed in their reference Laws and directives. In that regard, as it is seen from the above clarifications, SPAs' duties and powers have been determined in detail at the Law No. 5302 of SPA. IMCDs duties and powers have been counted in general, and the details are left to directives issued by the Ministry of Interior (Karaaslan et al., 2012: 126).

In addition to that, at the Article $10^{\text {th }}$ of the Law No. 6360, it was determined that 'The Ministry of Interior is authorized to remove the hesitations and to make the regulatory and the guidance process"21. By the provision of the Law No. 6360 that is described above, the task distribution between the central and local government is made, but that task distribution is left to the directives and regulation of the Ministry of Interior. At that point, one of the other striking differences lies in their legal functioning mechanisms. In this sense, SPAs are established by law and fulfill their duties and responsibilities under that law. At that point, the establishment of IMCD reached on its legal basis with the Law No. 6360 , but it was determined that any regulations related to IMCD are included in the Directive to be issued by the Ministry of Interior. At this context, at the comparison of the IMCD and SPA, it seen that the SPAs are the local government units having public legal entity, however IMCDs are the central government organization tied to Governor which are organized at the provincial level. In this scope, the SPAs are local government units that can prepare their regulation and budget, and they can employ staff with having a public legal personality; in contrast, the IMCDs have no public legal personality and they have no authority to make their directive and to prepare their budget.

\subsection{Within the Scope of Financial Structure:}

At the Law No. 5302, at the Article $45^{\text {th }}$ under the title of the preparation and adoption of the budget, it was determined that:

The draft budget drawn up by the governor shall be submitted to the executive committee. The executive committee shall examine the budget and submit it to the general provincial council, together with its opinion, by the first

${ }^{19}$ For Details, see, http://www.migm.gov.tr/en/Laws/Law5302_SpecialProvincialAdmin_2010-12-31_EN_rev01.pdf 'Law on Special Provincial Administration'.

20 For details, see, http://www.tbmm.gov.tr/kanunlar/k6360.html, 'On Üç IIlde Büyükşehir Belediyesi ve Yirmi altı Illçe Kurulması ile Bazı Kanun ve Kanun Hükmünde Karamamelerde Değişiklik Yapılmasına Dair Kanun'.

${ }^{21}$ For details, see, http://www.tbmm.gov.tr/kanunlar/k6360.html, 'On Üç Illde Büyükş̧ehir Belediyesi ve Yirmi altı Ilçe Kurulması ile Bazı Kanun ve Kanun Hükmünde Karamamelerde Değişiklik Yapılmasına Dair Kanun'. 
day of November. The general provincial council shall adopt the draft budget, unchanged or with amendments, before the beginning of the year. However, the council may not make amendments increasing expenditures and reducing revenues in such a manner as to impair budgetary balance ${ }^{22}$.

The approval of the budget of the SPAs to the Ministry of Interior application was removed by the Law No. 5302 (Coşkun \&Uzun, 2005: 171). According to that, the draft budget of the SPAs prepared by the Governor and adopted by the Provincial General Council in accordance with the opinion of the Provincial Executive Committee.

On the other hand, at the Law No. 6360 at the Article $34^{\text {th }}$, it is determined that adequate appropriation has been allocated to the Ministry of Interior for the realization of duties and responsibilities of IMCD. Besides, at the Article $34^{\text {th }}$ of the Law No 6360; it was clarified that;

The Ministries and other central government institutions with the provision of the transition of the required financial resource, those related institutions can make any investment, construction, maintenance, and repair affairs through the IMCD. The financial resource transfer that will be made by the public institutions within the context of the general budget is realized with appropriation transfer and the financial resource transfer that will be made by the other public institutions is performed by accrual procedures ${ }^{23}$.

As it is seen from the above clarification, IMCD has gained the possibility of using the resources of the municipality. Within the framework of the decentralization concept, which is generally referred as the transfer of powers from central government to lower levels in a political-administrative and territorial hierarchy (Crook \&Manor 1998, Agrawal \&Ribot 1999), it is seen that the central government is tried to be active in the whole administrative process at the evaluation of the financial formation of IMCD (Özer \&Sipahi, 2003: 56).

\subsection{Within the Scope of Organization and Personnel Structure:}

At the Law No. 5302, at the article $35^{\text {th }}$ with the title organization of the SPA, it is determined that;

The organization of the SPA shall consist of the general secretariat, units of financial affairs, health, agriculture, land development planning and control, human resources and legal affairs. Such units shall be established as divisions and branches in provinces having a metropolitan municipality and as branches in other provinces ${ }^{24}$.

On the other hand, at the Law No. 6360, it was determined that IMCD shall consist of disaster assistance, emergency call, investment monitoring, guidance and supervision, strategy and coordination, and administrative directives and, it is also clarified at the Directives that if it is entailed, temporary units can establish. It is also worth noting that at the Law No. 5302, the possibility of contract staff employment has been provided in addition to the officials (Supplementary third paragraph: 3/7/2005-5393/85 Art.). Article 49th of the Law on Municipality shall apply to the employment of contracted personnel and part-time contracted personnel in SPAs. Besides, at the Law No. 6360, it is determined that the Governorate has the authority to appoint specialist, contractual staff and officials in necessary conditions regardless of cadre, status, and title. In this context, the criteria of that requirement are not included in the text of the law No. 6360 (Karaaslan et al., 2012: 128; Coşkun \&Uzun, 2005: 172).

\section{Conclusion}

By the Law No. 6360 on 'The Establishment of Fourteen Metropolitan Municipalities and Twenty-seven Districts and Amendments At Certain Law and Decree Laws', the local government system has undergone radical changes in Turkey. In that context, the number of the metropolitan municipalities upgraded to 30, and SPAs were abrogated at those provinces having metropolitan municipalities. At that point, Gözübüyük (1967: 99-100) clatifications are worth to mention, the scholar puts forwards the view concerning the SPAs as follows: "to benefit from that organization with making some amendments to its organization and duties would be better rather than removing an existing organization, and those institutions should not be abrogated unless a major necessity. The benefits and the significance will emerge automatically by finding out the flaws and correcting them. In that framework, the tasks that are assigned to the SPAs should be clearly demonstrated, and adequate financial resource should be provided to respond to those local services". The SPAs that

22 For Details, see, http://www.migm.gov.tr/en/Laws/Law5302_SpecialProvincialAdmin_2010-12-31_EN_rev01.pdf 'Law on Special Provincial Administration'.

23 For details, see, http://www.tbmm.gov.tr/kanunlar/k6360.html, 'On Üç İlde Büyükşehir Belediyesi ve Yirmi altı Illçe Kurulması ile Bazı Kanun ve Kanun Hükmünde Kararnamelerde Değişiklik Yapılmasına Dair Kanun'.

${ }^{24}$ For Details, see, http://www.migm.gov.tr/en/Laws/Law5302_SpecialProvincialAdmin_2010-12-31_EN_rev01.pdf Law on Special Provincial Administration'. 
are one of the oldest local government units of Turkish local government system should be supported in terms of finance and staff for increasing the effectiveness of SPAs at the provision of services.

In that context, IMCDs' are established by the Law No. 6360 instead of SPAs that their public legal entities removed at the provinces where metropolitan municipalities established; however, there are significant differences between IMCD and SPA. First of all, one of the most prominent differences is focused on their administrative formations; SPAs are local government institutions, whereas IMCDs' have been stipulated as a local unit of the central government at the Metropolitan Municipality Law No. 6360. Furthermore, the internal and external supervision has been perceived for SPAs with the Law No. 5018; however, internal supervision has not been foreseen for IMCD. In this regard, IMCD is a part of the central government that IMCD is not subject to supervision by a local council. Besides, SPAs have no authority in the supervision of the other public institutions and organizations. However, IMCD has the supervision power in the public institutions and organizations in the province via the Report that will be prepared by IMCD. Moreover, as it was mentioned before, SPAs' duties and powers have been determined in detail at the Law No. 5302 of SPA. IMCDs duties and powers have been counted in general, and the details are left to directives issued by the Ministry of Interior. Besides, IMCD has gained the possibility of using the resources of the other local government units. Lastly, the organizational structure differs from SPA with consisting of disaster assistance, emergency call, investment monitoring, guidance and supervision, strategy and coordination and administrative directives. Consequently, the functioning of IMCDs should be analyzed from the administrative dimension at putting forth the possible strengths and the weaknesses in Turkey. There has been relatively little research on that newly established administrative formation; it's worth to increase the researches by case studies in a comparative perspective in Turkey.

\section{References}

Adıgüzel, Ş. (2012). 6360 sayıı yasa'nın türkiye'nin yerel yönetim dizgesi üzerine etkileri: eleştirel bir değerlendirme. Toplum ve Demokrasi, 6 (13-14): 153-176.

Agrawal, A. \& Ribot J. (1999). Accountability in decentralization: a framework with south asian and west african environmental cases. The Journal of Developing Areas, 33: 473-502

Alpay, I.H. (1965). II özel idareleri tarihçesi, Türk Idare Dergisi, Yıl 36, Sayı 295 (Temmuz - Ağustos 1965), pp. 3-31.

Ateş, H. \&Es, M. (2008). Süreklilikten değişime il özel idareleri, Recep Bozloğan\&Yüksel Demirkaya (Eds.). Türkiye'de yerel yönetimler, Nobel Yayınlarl: Ankara.

Arıkboğa, E. (2007). Türk yerel yönetim sisteminde reform ve yeni kamu yönetimi. (Ed.: B. Eryılmaz, M. Eken ve M. Lütfi Şen). Kamu Yönetimi Yazıları. Ankara: Nobel Yayın, 1. Baskı, pp: 42-71.

Başsoy, A. (1976). Mahalli idare birimi olarak il özel idareleri", Türk Idare Dergisi, 47 (356), pp. 66-71.

Bilgiç, V. K. (2007). Türk yerel yönetimlerinin tarihi gelişimine ilişkin bir değerlendirme. (Ed.: B. Eryılmaz, M. Eken \&M. Lütfi Şen). Kamu Yönetimi Yazıları. Ankara: Nobel Yayın, 1. Baskı, pp: 100-111.

Coşkun, B. \&Uzun, T. (2005). İl Özel İdaresi'nde Yeniden Yapılanma, (Eds.) H. Özgür\& M. Kösecik. Yerel Yönetimler Üzerine Güncel Yazılar I, (1. Edition), Nobel Yayın Dağııı: Ankara, 157-175.

Crook, R.\& Manor, J. (1998). Democracy and descentralisation in south asia and west africa. Cambridge University Press: Cambridge.

DPT, Mahalli Hizmetlerin Yerinden Karşılanması: VI. Beş Yıllık Kalkınma Planı Özel İhtisas Komisyonu Raporu, Ankara, DPT yayını

Genç, N. (2014). 6360 sayılı kanun ve Aydın'a etkileri, Adnan Menderes Üniversitesi, Sosyal Bilimler Enstitüsü Dergisi, 1 (Özel Sayı): 129.

Gözübüyük, A. Ş. (1967). Türkiye'de mahalli idareler. TODAIE Yayını:Ankara.

Güler, B.A. (1995), İ Özel İdaresi Harcamaları (1925-1990), Çağdaş Yerel Yönetimler Dergisi, 4(3), pp.11-25.

Güler, B.A. (2001). Yerel yönetimlerde reform sorunu, Çağdaş Yerel Yönetimler, 10 (3): 7-12.

Güler, B.A. (2005). Devlette reform yazıları: dünya'da ve türkiye'de ekonomik liberalizasyon siyasi-idari liberalizason, Paragraf Yayınevi: Ankara

Güler, B. A. (2006). Yerel yönetimler, liberal açılımlara eleştirel yaklaşım. İmge Yayınevi: Ankara.

Güler, B.A. (2012a). Hükümetin 8 ekim 2012 günlü bütünşehir yasa tasarısı üzerine, htttp: www.yayed.org.tr. (05.10.2013)

Güler, B.A. (2012b). Bütünşehir belediyesi, TBMM komisyon konuşmaları, 12, Kasım, 2012, Ankara.

Günday, M. (2005). Kamu yönetimi reformu'nun idari yapılanmaya ilişkin anayasal ilkeler açısından değelendirilmesi. Danıştay ve İdari Yargı Günü Sempozyumu, Ankara.

Güneş, A.F. (2013). Büyükşehirlerdeil Özel İdarelerinin Kaldırımasının Hukuki Veçhesi ve İşlevsel Sonuçları, http:/lwww.tid.web. tr/ortak_icerik/tid.web/154/13-\%20Ahmet\%20Faruk \%20G\%C3\%9CNE\%C5\%9E.pdf. (11.10.2014).

Güngör, H. (2012). Yeni büyükşehir yönetimi ve geçiş nedenleri. IIller ve Belediyeler Dergisi, Ekim-Kasım, 774-775: 28-31.

Güran, S. (1986). il özel İdarelerinin bugünkü rolü. il Özel İdaresi Sempozyumu, İstanbul III Özel İdaresi Yayını: İstanbul.

İzci, F. \& Turan, M. (2013) Türkiye'de büyükşehir belediye sistemi ve 6360 sayılı yasa ile büyükşehir belediye sisteminde meydana gelen değişimler: van örneği, Süleyman Demirel Üniversitesi IïBF Dergisi, 18 (1): 117-152.

Kapucu, N. \& Palabıyık, H.(2008). Turkish public administration: from tradition to modern age, International Strategic Research Organization: Ankara. 
Karaaslan, E., Ozansoy, A.,Yeğer, Ö. \& Soylu, H. (2012). 6360 sayılı 13 ilde büyükşehir ve 26 ilçe kurulması hakkında kanun, http://www.bekad.org/imgs/files/6360 \%20Say\%C4\% B1/\%C4\%B1\%20Kanun.pdf (12.01.2015).

Kartal, N.(2010). II özel idarelerinin yeniden yapılandırılması: uygulama aşaması üzerine bir inceleme, T.C.Anakara Üniversitesi Sosyal Bilimler Enstitüsü, Kamu Yönetimi ve Siyaset Bilimi Anabilim Dalı, Yayınlanmamış Doktora Tezi.

Kaya, S. (2011). İ Özel İdarelerinin Değişimi ve Dönüşümü: İstanbul İl Özel İdare Örneği, Nisan Mayıs Haziran, Dış Denetim, pp.27-38. http://www. sayder. org.tr/e-dergi-il-ozel-idarelerinin-degisimi-ve-donusumu-istanbul-il-ozel-idaresi-12-4.pdf. (12.04.2014).

Keleş, R.\&Yavuz, F. (1983). Yerel yönetimler. Turhan Kitapevi: Ankara.

Keleş, R. (1994). Kent ve siyaset üzerine yazılar, (1975-1992), IULA-EMME, İstanbul.

Keleş, R. (2000). Yerinden yönetim ve siyaset, 4. Edition, Cem Yayınevi: Ankara.

Kızılboğa, R. \& Özaslan, K. (2013). İ özel idaresi ile yatııı izleme ve koordinasyon başkanlığı'nın karşılaştırmalı olarak incelenmesi. KAYSEM-8 Kuramdan Uygulamaya Yerel Yönetimler ve Kentsel Politikalar Bildiri Kitabı 11-12 Mayıs 2013-Hatay.

Nalbant, A. (1997). Üniter devlet, Yapı Kredi Yayınları.

Ortaylı, İ. (1974). Tanzimattan sonra mahalli idareler, TODAIE: Ankara.

Ökmen, M. (2003). Yerel yönetimlerde yeniden düzenleme girişimleri ve son reform tasarıları üzerine bir değerlendirme. Yönetim ve Ekonomi Dergisi, Celal Bayar Üniversitesi I.I.B.B.F., 1(10), 2003, pp.118-139.

Özer, M. A. \& Esra B. S. (2003). Yönetişim yaklaşımı ve kamu yönetiminde kalite. Sayıştay Dergisi, Sayı: 50-51, Temmuz-Aralık, pp. 3566.

Parlak, B. \& Sobacı, Z. (2005). Kamu yönetimi, Alfa Aktüel: Bursa.

Pirler, O., Tortop, N.\&Başsoy, A., 1995, Belediyeler ve idari vesayet, Türk Belediyecilik Derneği, Ankara.

Reyhan, C. (2007). Osmanlıda iki tarz-ı idare, İmge Yayınevi: Ankara.

Sobacı, M. Z. (2005). Yeniden yapılanma sürecinde il özel idarelerinin dünü bugünü ve geleceği üzerine değerlendirmeler. Çağdaş Yerel Yönetimler, C.1.,31-50.

Şeyran, C. (1996). Türkiye'de il özel idarelerinin bugünkü durumu, sorunları ve çözüm önerileri, Basılmamış Yüksek Lisans Tezi, S.D.Ü., Isparta.

TOBB (1996), Mahalli idarelerin yeniden yapılandırıması özel ihtisas komisyonu raporu, TOBB Yayınları: Ankara.

Tortop, N., Aykaç, B., Yayman, H.\& Özer, M.A. (2006). Mahalli idareler, (1. Edition), Nobel Yayıncılık: Ankara.

Tortop, N., Aykaç, B., Yayman, H.\& Özer, M.A. (2014). Mahalli Idareler, (3. Edition), Nobel Yayıncılık: Ankara.

Ulusoy, A. \& Akdemir, T. (2008). Mahalli idareler, teori-uygulama-maliye, Seçkin Yayınevi: Ankara.

Urhan, V.F. (2008). Türkiye'de yerel yönetimlerin yeniden yapılandıııması. Sayıştay Dergisi. S:70, pp.85-102.

Ülkmen, I. H. (1960). Mahalli idareler maliyesi dersleri, Ankara Üniversitesi Siyasal Bilgiler Fakültesi yayını: Ankara.

Yayla, Y. (1982). Anayasalarımızda yönetim ilkeleri: tevsi-i mezuniyet ve tefrik-i vezaif, İstanbul Üniversitesi Siyasal Bilgiler Fakültesi yayını: İstanbul.

Zengin, O. (2013). An analysis of turkey regarding the decentralization and local government reform, $4^{\text {th }}$ International Conference on European Studies: Social, Economic and Political Transition of Balkans-Proceedings Book, Epoka University, Tiran/Arnavutluk 89 November 2013, 538-548.

Zengin, O. (2014). Büyükşehir belediyesi sisteminin dönüşümü: son on yılın değerlendirmesi, Ankara Barosu Dergisi, 72(2): 91-116. 